\title{
ANALISIS KEJADIAN BENCANA TANAH LONGSOR TANGGAL 12 DESEMBER 2014 DI DUSUN JEMBLUNG, DESA SAMPANG, KECAMATAN KARANGKOBAR, KABUPATEN BANJARNEGARA, PROVINSI JAWA TENGAH
}

\section{THE DECEMBER 12, 2014 LANDSLIDE DISASTER ANALYSIS IN JEMBLUNG AREA, SAMPANG VILLAGE, KARANGKOBAR SUBDISTRICT, BANJARNEGARA DISTRICT, CENTRAL JAVA PROVINCE}

\author{
Heru Sri Naryanto \\ Pusat Reduksi Risiko Bencana (PTRRB), Kedeputian TPSA-BPPT \\ Gedung 2 BPPT Lantai 12, JI. MH Thamrin 8, Jakarta \\ Lab. Geodinamika, Geostech, Kompleks Puspiptek, Serpong, Tangerang Selatan \\ e-mail: heru.naryanto@bppt.go.id ; naryantohs@yahoo.com
}

\begin{abstract}
Landslide events are becoming more frequent in Indonesia, including in Banjarnegara District. Landslides again struck in Jemblung area, Sampang Village, Karangkobar Sub district, Banjarnegara District, Central Java Province on Friday, December 12th, 2014 at 17:30 PM. Typology of landslide is the type of rotation, which then developed into a debris flow of material due to avalanche debris mixed with water masses are very saturated. Factors that influence the occurrence of landslides in Banjarnegara on December 12, 2014 include: geomorphology formed by moderate to steep hills, in the form of soil overburden derived from the weathering of volcanic breccias rock, rock formation of cracks in the top of the crown landslide, extreme rainfall, springs formed on the top and middle of the hill, which has a lot of land use change and human activities that have been plundering the critical region. Many factors that influence the occurrence of landslides, but the results of the analysis there are three main factors causing landslides are: extreme rain for three consecutive days before the landslide, landslide topography forming very steep, soil the result of weathering of rocks is very thick and absorbs water so easily saturated. For it is needed various activities disaster risk reduction (DRR) to minimize the number of victims of both life and property.
\end{abstract}

Keywords: Landslides, Banjarnegara, Steep Topography, Soil Thickness, Extreme Rainfall, Disaster Risk Reduction

\begin{abstract}
ABSTRAK
Kejadian bencana tanah longsor semakin sering terjadi di Indonesia, termasuk di Kabupaten Banjarnegara. Bencana tanah longsor kembali menimpa warga Dusun Jemblung, Desa Sampang, Kecamatan Karangkobar, Kabupaten Banjarnegara, Provinsi Jawa Tengah pada hari Jumat, 12 Desember 2014 jam 17.30 WIB. Tipologi tanah longsor yang terjadi adalah tipe rotasi, yang kemudian ke arah bawah berkembang menjadi aliran debris akibat material longsoran yang bercampur dengan massa air yang sangat jenuh. Faktor-faktor yang mempengaruhi terjadinya tanah longsor di Banjarnegara 12 Desember 2014 antara lain adalah: geomorfologi terbentuk oleh perbukitan di sedang sampai terjal, batuan penutup berupa soil berasal dari pelapukan batuan breksi vulkanik, terbentuknya rekahan batuan di bagian atas mahkota longsor, curah hujan yang sangat ekstrim, terbentuk mataair pada bagian atas dan tengah bukit, tataguna lahan yang sudah banyak berubah dan aktivitas manusia yang sudah menjarah daerah kritis. Banyak faktor-faktor yang mempengaruhi terjadinya tanah longsor, tetapi dari hasil analisis ada tiga faktor utama penyebab terjadinya tanah longsor
\end{abstract}


yaitu: terjadinya hujan ekstrim (lebat) selama tiga hari berturut-turut sebelum terjadi longsor, topografi pembentuk tanah longsor sangat terjal, tanah (soil) hasil pelapukan batuan sangat tebal dan bersifat menyerap air sehingga mudah jenuh. Berkaitan dengan hal tersebut sangat dibutuhkan berbagai kegiatan pengurangan risiko bencana (PRB) untuk meminimalisasi jumlah korban baik jiwa maupun harta.

Kata kunci: Tanah Longsor, Banjarnegara, Topografi Terjal, Soil Tebal, Curah Hujan Ekstrim, Pengurangan Risiko Bencana

\section{PENDAHULUAN}

\subsection{Latar Belakang Permasalahan}

Bencana tanah longsor atau gerakan tanah dari tahun ke tahun semakin sering terjadi di Indonesia, khususnya pada saat musim hujan. Kondisi tektonik di Indonesia yang membentuk morfologi tinggi, patahan, batuan vulkanik yang mudah rapuh serta ditunjang dengan iklim di Indonesia yang berupa tropis basah, sehingga menyebabkan potensi tanah longsor menjadi tinggi. Hal ini ditunjang dengan adanya degradasi perubahan tataguna lahan akhir-akhir ini, menyebabkan bencana tanah longsor menjadi semakin meningkat. Kombinasi faktor anthropogenik dan alam sering merupakan penyebab terjadinya longsor yang memakan korban jiwa dan kerugian harta benda. Upaya mitigasi diperlukan untuk meminimalkan dampak bencana longsor.

Tanah longsor adalah proses perpindahan massa batuan (tanah) akibat gaya berat (gravitasi). Longsor terjadi karena adanya gangguan kesetimbangan gaya yang bekerja pada lereng yakni gaya penahan dan gaya peluncur. Gaya peluncur dipengaruhi oleh kandungan air, berat masa tanah itu sendiri berat beban bangunan. Ketidakseimbangan gaya tersebut diakibatkan adanya gaya dari luar lereng yang menyebabkan besarnya gaya peluncur pada suatu lereng menjadi lebih besar daripada gaya penahannya, sehingga menyebabkan masa tanah bergerak turun. (Naryanto, 2011; Naryanto et al, 2010).

Tanah longsor terjadi karena dua faktor utama yaitu faktor pengontrol dan faktor pemicu. Faktor pengontrol adalah faktor-faktor yang memengaruhi kondisi material itu sendiri seperti kondisi geologi, kemiringan lereng, litologi, sesar dan kekar pada batuan. Faktor pemicu adalah faktor yang menyebabkan bergeraknya material tersebut seperti curah hujan, gempabumi, erosi kaki lereng dan aktivitas manusia (Naryanto, 2013).

Bencana tanah longsor kembali menimpa warga Banjarnegara, Provinsi JawaTengah. Bencana tanah longsor telah mengubur Dusun Jemblung, Desa Sampang, Kecamatan Karangkobar pada hari Jumat, 12 Desember 2014 pada jam 17.30 WIB. Dampak dari bencana tanah longsor menimbun akses jalan utara Banjarnegara-Dieng sepanjang $1 \mathrm{~km}$. Bencana tanah longsor tersebut telah menyebabkan 43 rumah yang dihuni sekitar 300 jiwa dari 53 keluarga tertimbun longsor. Jumlah warga Dusun Jemblung RT 05 RW 01 yang tertimpa longsor berjumlah 108 orang diluar warga dari tempat lain yang sedang melewati atau berkunjung di dusun tersebut. Selain itu, sejumlah mobil dan motor yang sedang melintas di jalan BanjarnegaraDieng-Pekalongan turut tertimpa longsor. Sumber tanah longsor berasal dari Bukit Telagagede yang berada di atas Dusun Jemblung dengan ketinggian sekitar 990-1.010 meter.

\subsection{Lokasi}

Lokasi penelitian adalah Dusun Jemblung, Desa Sampang, Kecamatan Karangkobar, Kabupaten Banjarnegara, Provinsi Jawa Tengah. Lokasi bencana tersebut terletak pada RT 05 RW 01 di Dusun Jemblung.

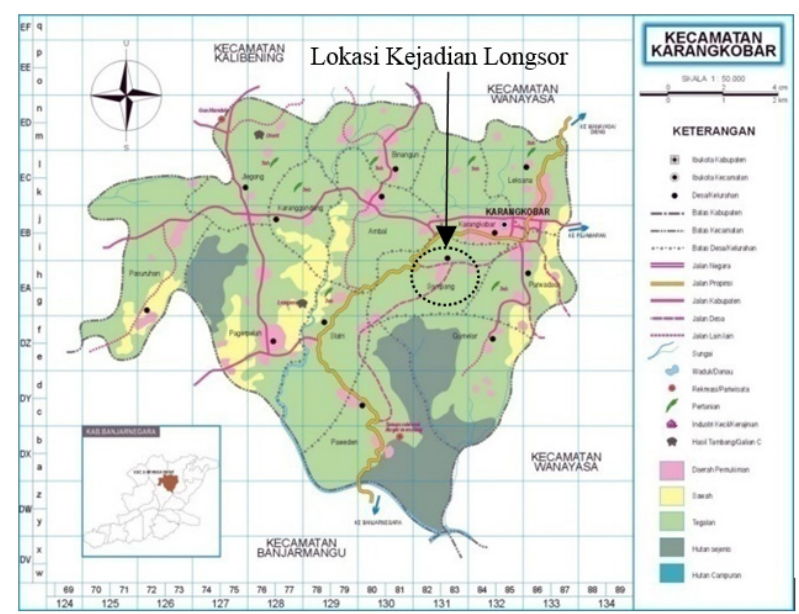

Gambar 1. Lokasi Dusun Jemblung Desa Sampang, Kecamatan Karangkobar, Kabupaten Banjarnegara (Sumber: BPS Kab. Banjarnegara, 2014). 


\subsection{Maksud dan Tujuan}

Maksud dari penelitian adalah untuk mengetahui fenomena terjadinya tanah longsor, dampak yang terjadi, faktor-faktor yang berpengaruh, dan analisis mekanisme kejadiannya. Dengan diketahuinya permasalahan bencana tanah longsor tersebut, maka dapat dilakukan penanganannya yang efektif dan efisien serta menjadikan acuan dalam pengurangan risiko bencana pada lokasi daerah lain yang mempunyai potensi bencana tanah longsor serupa.

\section{METODOLOGI}

Metodologi kajian yang dilakukan dalam melakukan adalah sebagai berikut:

- Koordinasi dengan instansi terkait (BNPB, BPBD Kabupaten Banjarnegara, BMKG, PVMBG, Universitas, K/L terkait)

- Kajian referensi/data sekunder berkaitan dengan bencana longsor di Dusun Jemblung, Desa Sampang, Kecamatan Karangkobar, Kabupaten Banjarnegara, Provinsi Jawa Tengah. Data sekunder mencakup kajian penelitian terdahulu tentang longsor yang terjadi, termasuk tentang daerah/lokasi, waktunya, catatan-catatan instansi terkait, cerita penduduk, geologi, geomorfologi, struktur geologi, geologi tata lingkungan, geologi teknik, foto udara curah hujan, DAS, keairan, sosial ekonomi, tata ruang/ RTRW, penggunaan lahan, penduduk dan lain-lain geologi tata lingkungan, geologi teknik, foto udara dan lain-lain. Pengukuran lapangan dengan menggunakan GPS Handheld dan kompas dengan teknik intersection, sementara penghitungan luas dilakukan dengan software ArcGIS.

- Survei lapangan pasca bencana tanah longsor secara komprehensif. Survei pasca longsor meliputi pengamatan dampak kejadian, luasan, kemiringan lereng, topografi, jenis litologi, pengukuran kekuatan tanah, tataguna lahan, kondisi hidrologi, curah hujan, mataair, DAS, tataguna lahan, jenis vegetasi, sosial ekonomi masyarakat, diskusi dengan masyarakat setempat/korban, pemetaan longsor, dan analisis mekanisme longsor pendahuluan.

- Pengolahan data referensi dan lapangan

- Analisis data

- Verifikasi data

- Laporan

\section{HASIL DAN PEMBAHASAN}

\subsection{Data Bencana}

Menurut informasi warga, hujan deras telah terjadi sejak Rabu (10/12/2014) sampai Jumat (12/12/2014) sebelum kejadian longsor. Pada saat kejadian tanah longsor, justru cuaca pada saat itu cukup cerah. Tidak diduga sama sekali oleh warga yang tinggal di sekitar areal tersebut sebelumnya, ternyata secara mendadak pada pukul 17.30 WIB material dari tebing tersebut runtuh, dan meluluhlantahkan permukiman yang berada di bawahnya. Tidak sampai lima menit longsoran tanah berbelok arah ke arah pemukiman dan menghancurkan seluruh rumah warga di Dusun Jemblung.

Beberapa korban yang telah teridentifikasi ada juga yang berasal dari daerah lain yang sedang beraktivitas di dusun Jemblung. Dusun Jemblung ini juga dilewati oleh jalan lintas yang menghubungkan Banjarnegara dengan daerah lainnya sehingga cukup ramai kendaraan yang melintas di desa ini.

Berdasarkan pendataan yang dilakukan Badan Penanggulangan Bencana Daerah (BPBD) Kabupaten Banjarnegara, jumlah pengungsi pada awal pasca bencana longsor Dusun Jemblung mencapai 1.146 jiwa yang tersebar di 10 lokasi dan terjadi penurunan jumlah pengungsi pada hari-hari setelah kejadian. Luas area terdampak bencana longsor ini \pm 12 ha.

Badan Nasional Penanggulangan Bencana (BNPB) dan BPBD Kabupaten Banjarnegara melaporkan sampai tanggal hari Minggu, 21 Desember 2014 tim SAR gabungan sudah menemukan sebanyak 95 orang korban tewas dan diperkirakan 24 lainnya masih terkubur belum diketemukan. Dari jumlah korban tewas tersebut sebanyak 64 warga asli Dusun Jemblung, sementara 31 korban meninggal berasal dari luar Dusun Jemblung. Pencarian korban dihentikan berdasarkan kesepakatan antara keluarga ahli waris, Pemda, TNI-POLRI dan para relawan, mengingat kondisi korban yang tertimbun longsor sudah 7 hari sehingga cukup berbahaya secara medis bagi relawan.

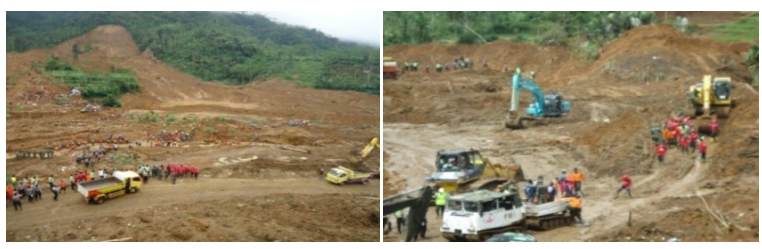

Gambar 2. Situasi Dampak Terjadinya Bencana

Tanah Longsor dan Kegiatan Kedaruratan yang Dilakukan oleh Tim SAR, Relawan, dan Masyarakat 


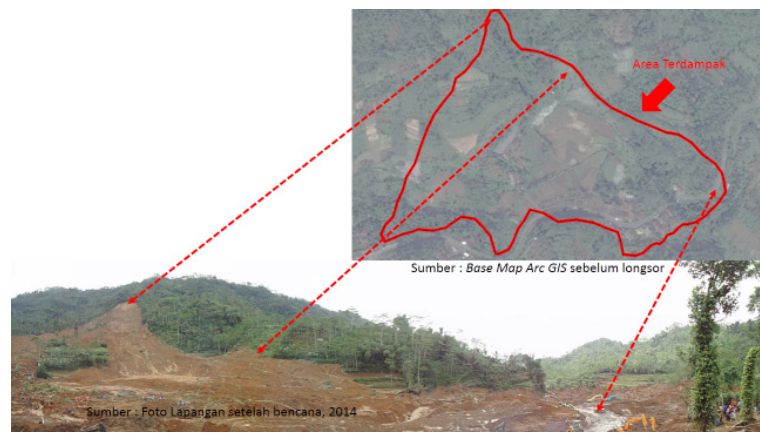

Gambar 3. Area Terdampak dan Peta Bencana Tanah Longsor di Dusun Jemblung (Putra, 2015)

Bantuan logistik makanan untuk para pengungsi telah tersedia dalam jumlah yang memadai. Bantuan itu dapat langsung didistribusikan ke lokasi-lokasi pengungsian. Pada awal pasca bencana evakuasi dengan alat-alat berat belum dapat difungsikan secara efektif, pencarian korban dilakukan dengan cara manual.

\subsection{Faktor-faktor yang Mempengaruhi Terjadi- nya Tanah Longsor di Banjarnegara 12 Desember 2015}

\subsubsection{Morfologi}

Secara umum, geomorfologi terbentuk oleh perbukitan di sedang sampai terjal. Di bagian bawah perbukitan ini terdapat geomorfologi perbukitan bergelombang sedang yang dipergunakan sebagai tempat pemukiman penduduk, pesawahan, dan perkebunan.

Kemiringan lereng yang diamati pada daerah bukit Telagalele yang merupakan tebing sangat terjal bagian selatan (daerah awal terjadinya longsor) sekitar $75^{\circ}$ dari puncak mahkota longsor. Kemiringan lereng di bawahnya lebih landai lagi yang digunakan untuk permukiman, persawahan dan perladangan. Ketinggian mahkota longsor adalah 990-1.010 meter di atas permukaan laut (dpal). Jarak antara mahkota longsor dengan titik akhir terpanjang ke arah barat laut sekitar 600 meter. Arah dari posisi tengah mahkota longsor adalah $\mathrm{N} 190^{\circ} \mathrm{E}$.

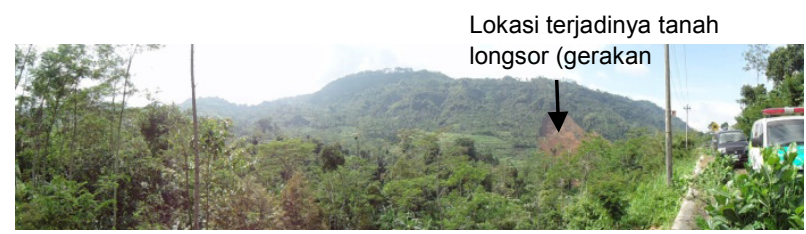

Gambar 4. Lokasi Terjadinya Tanah Longsor Terbentuk oleh Morfologi yang Terjal

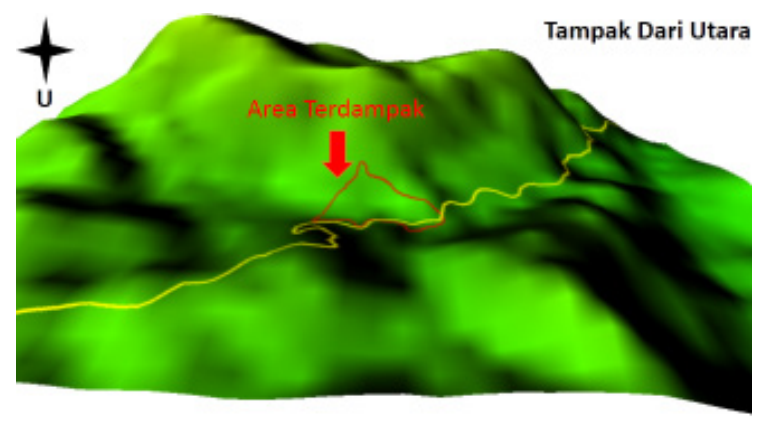

Gambar 5. Profil Morfologi Area Terdampak Sebelum Bencana Longsor (Sumber Radar Topographic Map, yang Diolah dengan Global Mapper) (Putra, 2015)

\subsubsection{Batuan}

Menurut peta geologi dari Condon et al (1975), batuan yang terdapat di Dusun Jemblung, Desa Sampang, Kecamatan Karangkobar dan sekitarnya terbentuk oleh Satuan Qiya, Qjm, Qjma, Qjo merupakan lava andesit dan batuan klastika gunungapi dari gunungapi yang tersayat dari Pegunungan Jembangan, terutama andesithiperstenaugit; setempat-setempat mengandung hornblende dan setempat-setempat basal olivin. Qiya dan Qjma merupakan lahar dan endapan aluvium yang terdiri dari bahan rombakan gunungapi, serta aliran lava dan breksi aliran dalam jumlah yang tidak begitu banyak. Satuan Qjm dan Qjo merupakan aliran lava, breksi aliran, breksi piroklastika, lahan dan endapan alluvium.

Batuan penutup berupa soil di bagian atas, berasal dari pelapukan batuan breksi vulkanik. Breksi vulkanik banyak mengandung tufa dan material lain yang mudah mengalami pelapukan, sehingga bisa membentuk soil dengan ketebalannya lebih dari 5 meter. Di beberapa tempat terlihat pula soil hasil pelapukan dari batuan tufa yang berwarna coklat muda kekuningan.

Lapisan soil kemudian bergradasi ke batuan breksi vulkanik yang relatif tidak terlapukan di bagian bawahnya (ukuran komponen antara pasir sampai dengan bongkah, besar komponen ratarata sekitar $5-10 \mathrm{~cm}$; dengan matriks pasir halus - lanau).

Di bagian bawah material lapuk (soil) yang berupa batuan breksi vulkanik, terdapat bidang batas antara batuan lunak dan batuan keras yang berfungsi sebagai bidang gelincir longsor apabila terjadi kejenuhan akibat masuknya air ke dalam pori-pori tanah. 


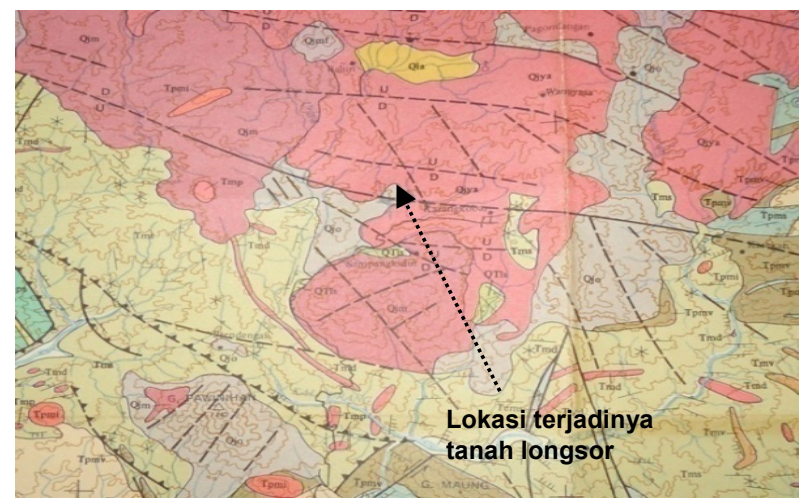

Gambar 6. Peta Geologi Dusun Jemblung, Desa Sampang, Kecamatan Karangkobar dan sekitarnya (Sumber: Condon et al, 1975)
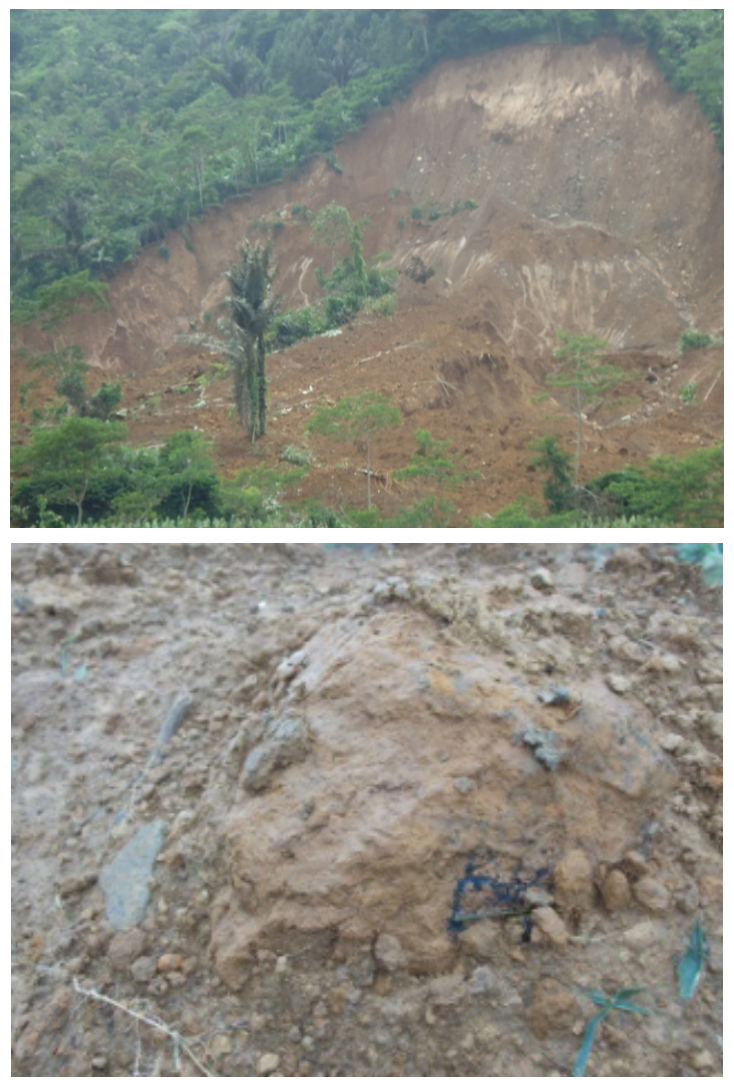

Gambar 7. Batuan Jenis Breksi Vulkanik Pembentuk Morfologi Tinggi yang Telah Mengalami Pelapukan Sangat Tinggi

\subsubsection{Rekahan Batuan}

Sebelum kejadian longsor biasanya didahului dengan terbentuknya rekahan/retakan batuan yang terjadi di bagian atas mahkota longsor. Dijumpai adanya rekahan di atas bukit yang longsor sebagai pertanda terjadinya ketidakstabilan lereng. Rekahan ini menyebabkan air hujan yang jatuh dapat lebih mudah untuk meresap ke dalam tanah dan mempermudah terjadinya kejenuhan tanah.

\subsubsection{Curah Hujan}

Kondisi curah hujan yan sangat ekstrim menjadi salah satu pemicu bencana tanah longsor di Dusun Jemblung. Curah hujan harian yang terjadi sebelum terjadi longsor sudah mencapai di atas $100 \mathrm{~mm}$. Menurut informasi warga setempat, hujan lebat tersebut telah terjadi mulai dari hari Rabu sampai Jumat (10-12 Desember 2014) secara berturutturut.

Menurut data dari BMKG, curah hujan tertinggi di Banjarnegara tercatat di Sigaluh pada hari Jumat, yaitu $153 \mathrm{~mm}$. Curah hujan harian yang terpantau di dua daerah sekitar Banjarnegara, yaitu Wonosobo dan Wonogiri. Di Wonosobo curah hujan tertinggi terpantau berada di Bedakah pada hari Kamis sebesar $150 \mathrm{~mm}$. Di Wonogiri, curah hujan tertinggi berada di Jati Purno pada hari Jumat, yaitu sebesar $139 \mathrm{~mm}$.

Stasiun geofisika kelas III Banjarnegara yang dioperasikan oleh BMKG (Badan Meteorologi Klimatologi dan Geofisika) mencatat curah hujan sepanjang Kamis 11 Desember 2014 mencapai 112,7 milimeter, sehari kemudian curah hujannya masih sebesar 101,8 milimeter. Dalam dua hari saja intensitas hujan yang mengguyur seluruh wilayah Banjarnegara telah sebesar 214,5 milimeter. Di waktu-waktu sebelumnya, pada umumnya curah hujan sebanyak itu membutuhkan waktu sebulan penuh. Curah hujan sepanjang 11-12 Desember 2014 di Banjarnegara berkualifikasi hujan sangat deras atau hujan ekstrim.

BPPT (2015) telah melakukan kajian terhadap rata-rata curah hujan harian di Banjarnegara pada hari-hari sebelumnya yaitu tanggal 9-11 Desember 2014, dan menunjukkan curah hujan rata-rata harian yang tinggi, yaitu di atas $100 \mathrm{~mm}$ (Gambar 8).

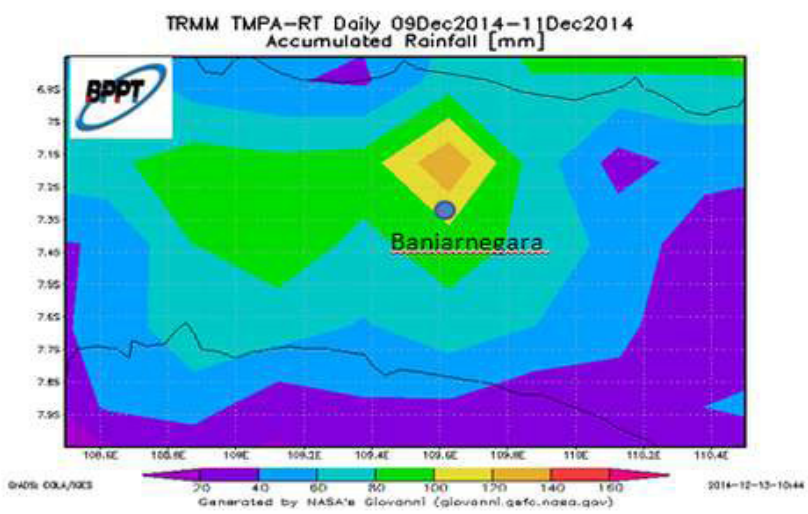

Gambar 8. Spasial Rata-Rata Curah Hujan Harian Banjarnegara 9-11 Desember 2014 (BPPT, 2014) 


\subsubsection{Mataair}

Mataair terbentuk pada bagian atas dan tengah bukit Telagalele. Mataair tersebut terlihat jelas termasuk dilihat dari jarak jauh setelah kejadian bencana tanah longsor. Dari kejauhan terlihat adanya torehan-torehan pada tebing longsor membentuk alur-alur baik di bagian bawah mahkota longsor di bagian barat maupun timur.

Keberadaan mataair termasuk sangat berpengaruh terhadap kejenuhan batuan yang dilaluinya. Curah hujan yang ekstrim yang terjadi terus-menerus menyebabkan debit mataair tersebut juga membesar, sehingga soil hasil pelapukan batuan yang dilaluinya menjadi semakin cepat jenuh.

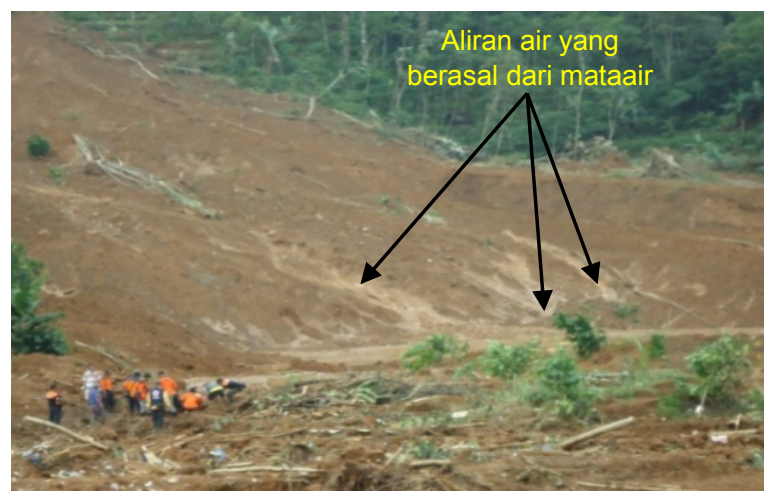

Gambar 9. Aliran Air yang Mengalir dari Mataair yang Berasal Bagian Atas dan Tengah Mahkota Longsor yang Terpotong Topografinya

Pada bagian tengah bukit juga nampak aliran air yang mengalir liar terbuang ke bawah melewati alur alami di antara reruntuhan tanah pasca terjadinya longsor (setelah hari ke-5 pasca longsor), dan makin ke bawah makin besar mengalir ke sungai di bagian barat yang debitnya cukup besar. Sementara itu lahan pada kaki bukit ditunjang oleh sistem drainase yang sekaligus berfungsi sebagai saluran irigasi untuk budidaya pertanian padi sawah (Soewandita, 2015).

\subsubsection{Pola Budidaya Pertanaman/Vegetasi}

Meskipun merupakan perbukitan dengan kelerengan yang tergolong curam hingga sangat curam, perbukitan di sekitar lokasi kejadian bencana longsor telah dimanfaatkan untuk budidaya tanaman. Dari segi aspek konservasi tanah, lahan dengan kelerengan $>45 \%$ (sangat curam) tidak cocok untuk budidaya tanaman dan harus merupakan kawasan konservasi/lindung. Namun apabila dilihat dari areal terdampak longsor morfologi lahan pada kaki bukit relatif mempunyai kemiringan lereng kurang dari 45\%. Pada lahan ini dimanfaatkan untuk persawahan padi sawah pada kaki bukit hingga pertengahan dan pada kawasan yang lebih atas (upland), lahan dimanfaatkan untuk pertanian tegalan dan pola pertanian agroforestry.

Pola pertanaman tegalan yaitu dengan tanaman jagung, kacang panjang, singkong, rumput gajah dan tanaman kobis. Pada pola pertanian tegalan beberapa petakan lahan disisipkan/diselingi juga pertanaman kayu/ pohon seperti secara kebanyakan tanaman sengon. Beberapa jenis pertanaman kayu juga terdapa tanaman Jabon seperti yang terdapat di sebelah timur kawasan terdampak. Pola agroforestry juga telah diterapkan pada lahan kawasan pertengahan bukit dan bagian puncak/upland. Nampak pertanaman agroforestry adalah tanaman kopi dan sengon atau tanaman salak dan sengon. Pola campuran seperti tegalan dan kebun campuran juga nampak pada bagian upland seperti pola pertanaman aren/sagu, sengon, nangka, pisang dan jagung. Sistem pengelolaan lahan dari bagian bawah hingga upland telah menerapkan sistem terasering dengan tujuan untuk konservasi tanah (Soewandita, 2015).
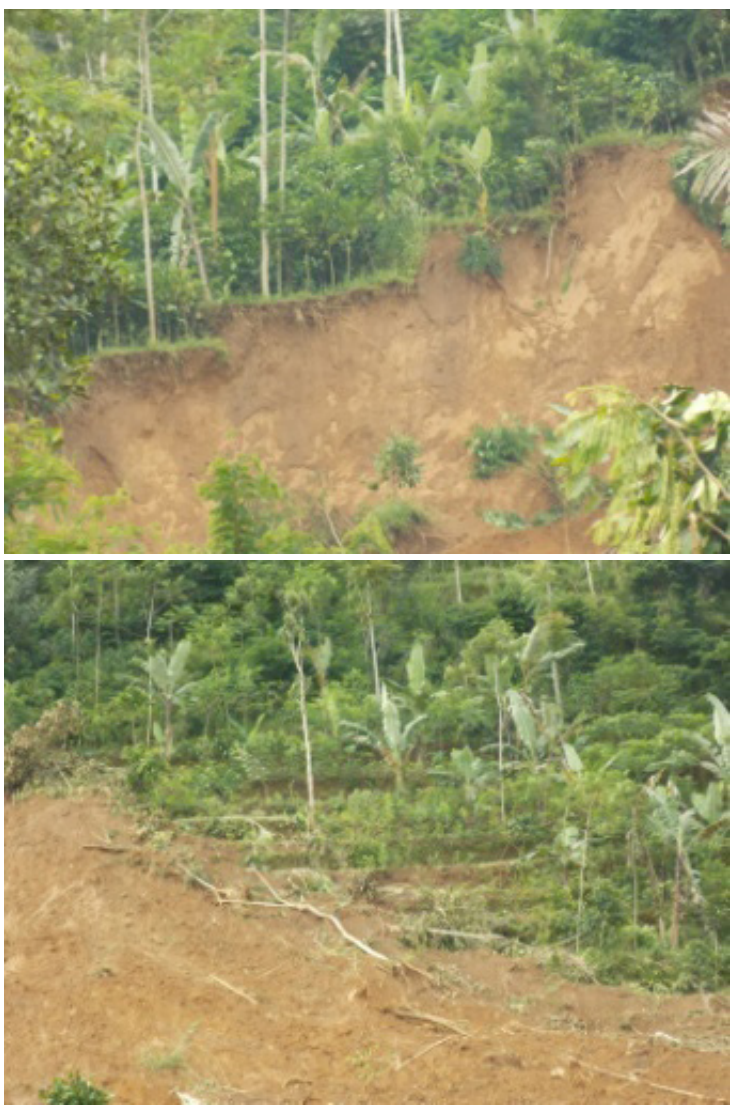

Gambar 10. Pola Budidaya Pertanaman Sawah Tadah Hujan, Tegalan dan Agroforesty di Sekitar Mahkota Longsor 


\subsubsection{Aktivitas Manusia}

Faktor manusia seringkali menjadi faktor kunci terjadinya bencana, termasuk untuk bencana tanah longsor. Ketidakseimbangan tanah akibat salah pengelolaan budidaya manusia yang secara kumulatif dapat memicu terjadi longsor. Kepala keluarga yang tertimbun longsor mempunyai mata pencaharian bertani. Mulai dari padi sawah, jagung, sengon, rumput gajah, kopi, bambu, dan lain-lain. Mereka bertani di sekitar rumahnya dan rata-rata bukan petani penggarap melainkan mereka bertani di lahan milik mereka sendiri.

Aktivitas bertani mereka juga bukan tanpa ilmu yang tidak mempertimbangkan konservasi air dan tanah. Terlihat dari pembuatan sengkedan/ terasering pada lahan miring, adanya irigasi, dan pembuatan DAM. Semangat bertani yang menyesuaikan dengan keadaan alam sangat nampak pada keseharian mereka. Namun faktor litologi yang membuat cara melakukan konservasi air dan tanah yang mereka lakukan kurang sempurna.

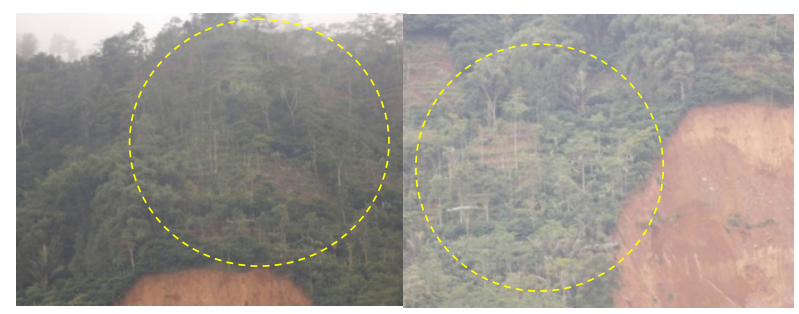

Gambar 11. Aktivitas Manusia Sudah Sampai Menjarah Puncak Bukit Termasuk di Bagian Atas dan Samping Mahkota Longsor

\subsection{Analisis Kejadian Tanah Longsor}

\subsubsection{Tipologi Longsor}

Berdasarkan analisis, tipologi tanah longsor yang terjadi di Dusun Jemblung adalah tipe rotasi, yaitu gerakan massa tanah yang membentuk cekungan atau tapal kuda, yang kemudian ke arah bawah berkembang menjadi aliran debris akibat material longsoran yang bercampur dengan massa air yang sangat jenuh.

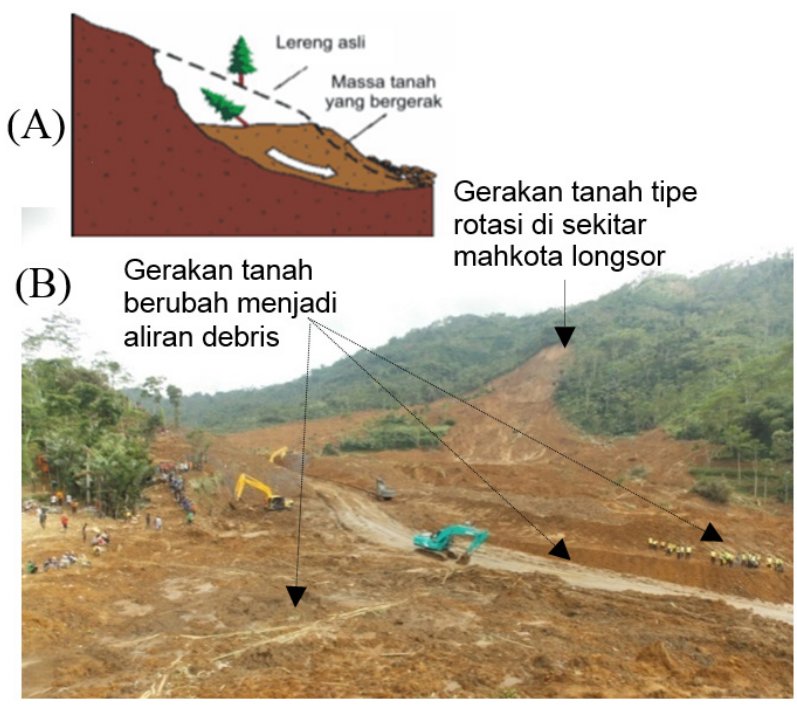

Gambar 12. Contoh Tipologi Tanah Longsor Tipe Rotasi (A) Tipe Tanah Longsor Rotasi pada Bagian Mahkota yang Berubah Menjadi Aliran Debris Karena Bercampur Dengan Massa Air yang Sangat Jenuh (B)

\subsection{Faktor Dominan yang Berpengaruh Terhadap Tanah Longsor}

Banyak faktor-faktor yang mempengaruhi terjadinya tanah longsor, tetapi dari hasil analisis faktor-faktor utama yang berpengaruh terhadap bencana tanah longsor di Banjarnegara ada tiga (3), adalah:

- Hujan deras/ekstrim selama 3 hari berturutturut pada hari Rabu sampai Jumat dengan curah hujan harian $>100 \mathrm{~mm}$.

- Morfologi pada sumber terbentuknya tanah longsor mempunyai kelerengan curam $\left(75^{\circ}\right)$.

- Batuan breksi vulkanik yang mudah lapuk yang membentuk soil hasil pelapukan sangat tebal (lebih dari 5 meter), mempunyai sifat menyerap air sangat tinggi sehingga mudah jenuh dan membuat ketidakstabilan lereng.

\subsection{Mekanisme Terjadinya Tanah Longsor}

Berdasarkan pengamatan di lapangan serta informasi yang didapat dapat diprediksi mekanisme terjadinya longsor yaitu sebagai berikut:

- Lokasi longsor berada di cerukan yang sisisisinya berupa tebing curam. Dengan kondisi seperti itu tempat tinggal Dusun Jemblung berada di daerah rawan longsor.

- Kondisi lapangan tersusun oleh batuan breksi vulkanik yang membentuk perbukian yang sangat curam. Batuan tersebut telah membentuk soil atau tanah hasil pelapukan 
batuan yang sangat tebal. Dijumpai adanya rekahan/retakan di atas bukit yang longsor sebagai pertanda ketidakstabilan lereng. Rekahan ini menyebabkan air hujan yang jatuh dapat lebih mudah untuk meresap ke dalam tanah.

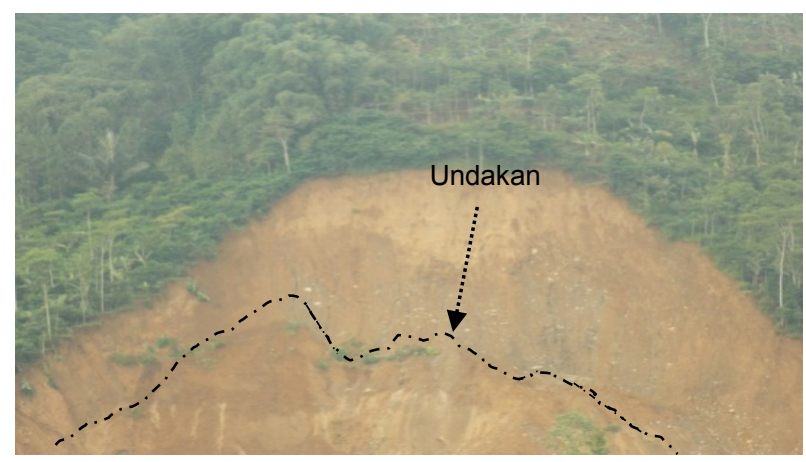

Gambar 13. Material Batuan Breksi Vulkanik, Mahkota Longsor dan Undakan yang Terbentuk di Bagian Atas Lereng Akibat Tertahan Fragmen Batuan yang Sangat Keras

- Pada bagian atas dan samping mahkota longsor kelihatan rekayasa terasering untuk pemanfaatan lahan, yang seharusnya bisa dijadikan hutan dengan akar yang kuat. Air hujan yang masuk melalui rekahan maupun melalui proses infiltrasi biasa kemudian menjenuhkan tanah penutup hingga ke batuan breksi vulkanik. Di dasar longsor terlihat jelas jenis batuannya yaitu breksi vulkanik yang masih keras. Karena curah hujan tinggi, tanah mudah menjadi jenuh dan breksi tersebut semakin jenuh dengan air dan air tidak dapat terinfiltrasi lebih jauh karena keras dan bidang batas tersebut berfungsi sebagai bidang gelincir.

- Pemicu utama dari kejadian bencana tanah longsor tersebut adalah curah hujan ekstrim yang telah terjadi selama tiga hari berturut-turut. Dari data BMKG diketahui bahwa jumlah hari hujan pada tiga hari terakhir sebelum terjadinya tanah longsor sangat tinggi, yaitu rata-rata lebih dari $100 \mathrm{~mm} /$ hari dan curah hujan tertinggi di Banjarnegara tercatat di Sigaluh pada hari Jumat, yaitu $153 \mathrm{~mm}$.

- Mataair muncul di bagian tubuh longsor atau di bagian atas dan tengah, akibat curah hujan yang tinggi maka air yang berasal dari mataair tersebut masuk ke dalam batuan. Debit mata air tersebut menjadi semakin besar dengan semakin tingginya curah hujan yang terjadi, sehingga munculnya mataair ini sangat mempengaruhi terhadap peningkatan kejenuhan soil yang dilaluinya.
- Tanah yang mengandung air menjadi semakin jenuh oleh karenanya demikian pula semakin berat massanya. Tekanan hidrostatis diperkirakan timbul pada batas antara lapisan soil yang jenuh air dengan lapisan breksi vulkanik yang relatif kedap air. Sehingga terdapat gaya angkat terhadap massa batuan breksi dan tanah penutup yang jenuh tersebut.

- Hujan yang menerus mengakibatkan sebagian air tertahan di bagian atas dan tengah tubuh longsor dan membentuk kejenuhan yang luar biasa pada tanah (soil). Air semakin lancar masuk ke dalam pori-pori tanah sampai batas kontak dengan batuan dasarnya. Pada saat beban massa tanah sudah lewat maka kestabilan lereng terganggu dan longsor dahsyat terjadi sekitar pada tanggal 12 Desember 2014 jam 17.30 WIB.

- Kondisi ketidakstabilan lereng kemudian terjadi pada lokasi lereng di bagian puncak bukit, jatuh secara slumping dengan cepat dari ketinggian 990-1.010 meter di atas permukaan laut (dpal), materialnya terlihat menghantam pohon budidaya masyarakat di tebing terbelah menjadi dua di sebelah timur laut dan barat laut. Material yang meluncur ke arah vertikal ke bawah yang karena tertahan oleh fragmen batuan yang sangat keras (fragmen boulder dari breksi vulkanik) dan membentuk undakan pada ketinggian 375 meter dpal. Hantaman ke arah selatan yang merupakan garis tegak lurus arah longsoran ternyata mengenai material yang keras sehingga berbelok ke lereng kanan dan kirinya, kemudian material longsoran berbelok ke arah barat laut dan timur laut yang kemudian ke segala arah yang mempunyai morfologi rendah menghancurkan 43 rumah warga dalam waktu lima menit. Sementara bagian bawah vertikal justru aman dari material longsor dan dijumpai 1 rumah dalam kondisi aman. 


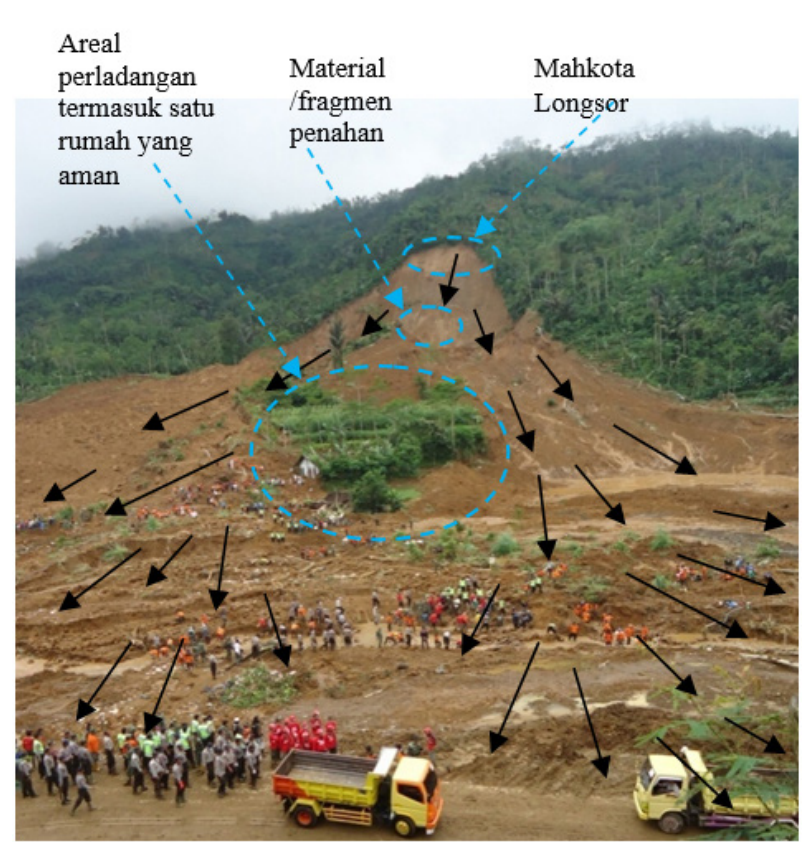

Gambar 14. Mekanisme dan Arah Gerakan Massa Tanah dari Sumber Longsor

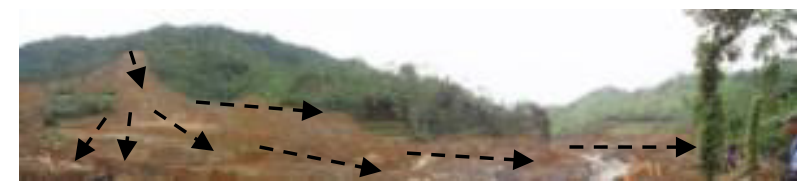

Gambar 15. Areal Terdampak dan Arah Gerakan Tanah Longsor ke Arah Sisi Utara (Vertikal ke Bawah) dan ke Arah Barat Laut dan Barat

\section{KESIMPULAN DAN SARAN}

Dari hasil pembahasan di atas bisa disimpulkan dan disarankan sebagai berikut:

- Ada tiga faktor utama penyebab terjadinya tanah longsor di Dusun Jemblung, Desa Sampang, Kecamatan Karangkobar pada 12 Desember 2014 adalah: a) Terjadinya hujan ekstrim selama tiga hari berturut-turut, b) Topografi pembentuk tanah longsor sangat terjal, c) Tanah (soil) hasil pelapukan batuan sangat tebal dan bersifat menyerap air sehingga mudah jenuh.

- Kemiringan lereng sekitar $75^{\circ}$ dari puncak mahkota longsor, kemiringan lereng di bawahnya lebih landai.

- Batuan penutup berupa soil di bagian atas, berasal dari pelapukan batuan breksi vulkanik. Breksi vulkanik yang membentuk soil lebih dari 5 meter.

- Kondisi curah hujan yan sangat ekstrim menjadi salah satu pemicu bencana tanah longsor di
Dusun Jemblung. Curah hujan harian yang terjadi sebelum terjadi longsor sudah mencapai di atas $100 \mathrm{~mm}$. Hujan lebat tersebut telah terjadi mulai dari hari Rabu sampai Jumat (1012 Desember 2014) secara berturut-turut.

- Mata pencaharian penduduk sebagian besar bertani dan berkebun sampai lahan yang terjal dan terlihat banyaknya sengkedan/terasering pada lahan miring di atas dan samping mahkota longsor, sehingga sangat membantu dalam proses peresapan air hujan dan kejenuhan tanah.

- Jenis tanaman yang berada di sekitar mahkota longsor tidak mempunyai akar yang panjang yang hanya menggantung pada soil yang ada, sehingga ada saatnya justru menjadi beban terhadap massa tanah yang sudah menjadi jenuh air.

- Perlu manajemen soil dengan baik, seperti ditanami tanaman keras yang berakar kuat sampai menembus ke batuan dasarnya, menghindari kejenuhan yang berlebihan, pengaturan saluran air, tidak diganggu keberadaan soil yang kritis.

- Dibuatkan saluran air permukaan yang baik dan teratur untuk menjaga kestabilan lereng.

- Pada musim hujan bagi penduduk yang tinggal di zona kerentanan gerakan tanah tinggi, supaya selalu siap siaga dan waspada terhadap kemungkinan terjadinya gerakan tanah. Zona kerentanan gerakan tanah tinggi, sebaiknya tidak dikembangkan sebagai daerah pemukiman.

- Dipasang peralatan sistem peringatan dini longsor pada daerah-daerah padat penduduk yang tanahnya bergerak, baik berbasis gerakan pergerakan massa batuan, kejenuhan batuan maupun curah hujan.

- Relokasi harus dilakukan, untuk menentukan tempat relokasi sebaiknya melibatkan ahli longsor.

\section{DAFTAR PUSTAKA}

Badan Penanggulangan Daerah (BPBD) Kabupaten Banjarnegara, 2014. Data Bencana Tanah Longsor di Dusun Jemblung, Desa Sampang, Kecamatan Karangkobar.

BPPT, 2014. Kajian Spasial Rata-Rata Curah Hujan Harian Banjarnegara 9-11 Desember 2014. Laporan Intern, tidak dipublikasikan.

BPS Kabupaten Banjarnegara, 2014. Kecamatan Dalam Angka Kecamatan Karangkobar 2014. Pemerintah Kabupaten Banjarnegara. 
Condon, W.H., Pardyanto, L., Ketner, K.B., 1975. Lembar Peta Geologi Lembar Banjarnegara dan Pekalongan, Jawa, Skala $1: 100.000$. P3G, Bandung.

Naryanto, H.S., 2011. Analisis risiko bencana tanah longsor di Kabupaten Karanganyar, Provinsi Jawa Tengah. Jurnal Penanggulangan Bencana, BNPB.

Naryanto, H.S., 2013, Analisis dan evaluasi kejadian bencana tanah longsor di Cililin, Kabupaten Bandung Barat, Provinsi Jawa Barat Tanggal 25 Maret 2013, JSTMB, Vol. 8, No. 1, Tahun 2013, hal. 39-49.

Naryanto, H.S., Soewandita, H., \& Putra, A.P., 2015. Fakta dan Analisis Kejadian Bencana Tanah Longsor (Gerakan Tanah) di Dusun Dusun Jemblung, Desa Sampang, Kecamatan Karangkobar, Banjarnegara Tanggal 12 Desember 2014. Laporan Kajian Cepat (Rapid Assessment), BPPT, tidak dipublikasikan.

Naryanto, H.S., Wisyanto, Purwonugroho, S.P., Tejakusuma, I.G., Marwanta, B., \& Prawiradisastra, S., 2010. Pengkajian dan Penerapan Teknologi Model Pemantauan Kawasan Rawan Bencana Tanah Longsor di Kabupaten Tawangmangu, Provinsi Jawa Tengah. BPPT, Laporan, tidak diterbitkan.
Putra, A.P., 2015, Pemetaan Morfologi dan Batas Areal Terdampak Bencana Tanah Longsor di Dusun Jemblung, Desa Sampang, Kecamatan Karangkobar, Banjarnegara, PTLWB-BPPT, Laporan Intern, tidak dipublikasikan.

Soewandita, H., 2015. Faktor Tanah dan Tataguna Lahan Yang Berpengaruh Terhadap Bencana Tanah Longsor di Dusun Jemblung, Desa Sampang, Kecamatan Karangkobar, Banjarnegara. PTLWB-BPPT, Laporan Intern, tidak dipublikasikan.

\section{UCAPAN TERIMA KASIH}

Penulis mengucapkan terima kasih kepada Sdr. Hasmana Soewandita dan Sdr. Ahmad Pratama Putra atas kerjasamanya, yang telah banyak membantu dalam pengumpulan data di lapangan, pemetaan, diskusi, intepretasi, dan analisisnya. 